\title{
Memoirs of E. A. Malov as an important educational resource in the field of "propaganda science"
}

\section{Memorias de E. A. Malov como importante recurso educativo en el campo de la "ciencia de la propaganda"}
Vladimir Vasilievich Astafiev
Ph.D. in History, Associate Professor at the Department of National History, the Higher School of History and World Cultural Heritage, the Institute of International Relations, Kazan Federal
University
ORCID: 0000-0002-2996-903X

\section{Artem Valentinovich Krestyaninov}

Ph.D. in History, Lecturer at the Department of National History, the Higher School of Historical

Sciences and World Cultural Heritage, the Institute of International Relations, Kazan Federal University

ORCID: 0000-0001-9833-1817

Received 09-08-20 Revised 10-10-20

Accepted 20-12-21 On line 03-17-21

* Correspondence

Email: Vladimir.Astaviev@ksu.ru 


\section{Summary}

The article is devoted to the autobiographical texts by E.A. Malov, a missionary and a teacher of the Kazan Theological Academy during the second half of the 19th - early 20th centuries. This period of time was characterized by a massive apostasy in the Kazan province of Orthodox newly baptized and old-baptized "foreigners" to Islam or paganism, which largely predetermined the specifics of the academy scientific work and its professors. The texts are written in the form of a diary describing the reflections on the implementation of a missionary campaign among Muslims and Orthodox "foreigners" and the conversations with shakirds and mullahs of the Kazan province during the second half of the 19th - early 20th centuries. E.A. Malov's diaries are directly related to his missionary activity, in which he participated actively throughout his life. Unlike many autobiographical texts that belonged to the clergy of that period, the Kazan missionary's diaries do not reflect the facts from his personal, and family life. The author of the diaries formulated the principles of "missionary science", the methods of refuting paganism and the Islamic religion. The texts of the diaries show that E.A. Malov strove to establish clear disciplinary boundaries of "missionary science," based mainly on historical criticism of sources, requiring specialized training. It is concluded that this source can be considered as one of the valid educational references in the field of propaganda science.

Key words: E.A. Malov, confessional politics, autobiography, missionary diaries, "foreigners", Orthodox mission, Educational resource.

\section{Resumen}

El artículo está dedicado a los textos autobiográficos de E.A. Malov, misionero y profesor de la Academia Teológica de Kazán durante la segunda mitad del siglo XIX y principios del XX. Este período de tiempo se caracterizó por una apostasía masiva en la provincia de Kazán de "extranjeros" ortodoxos recién bautizados y antiguos bautizados al Islam o al paganismo, que predeterminó en gran medida los detalles del trabajo científico de la academia y sus profesores. Los textos están escritos en forma de diario que describe las reflexiones sobre la implementación de una campaña misionera entre musulmanes y ortodoxos "extranjeros" y las conversaciones con shakirds y mullahs de la provincia de Kazán durante la segunda mitad del siglo XIX y principios del XX. E.A. Los diarios de Malov están directamente relacionados con su actividad misionera, en la que participó activamente a lo largo de su vida. A diferencia de muchos textos autobiográficos que pertenecieron al clero de ese período, los diarios del misionero de Kazán no reflejan los hechos de su vida personal y familiar. El autor de los diarios formuló los principios de la "ciencia misionera", los métodos para refutar el paganismo y la religión islámica. Los textos de los diarios muestran que E.A. Malov se esforzó por establecer límites disciplinarios claros de la "ciencia misionera", basada principalmente en la crítica histórica de las fuentes, que requería una formación especializada. Esta fuente puede considerarse como una de las referencias educativas válidas en el campo de la ciencia de la propaganda. Se concluye que esta fuente puede considerarse como uno de los referentes educativos válidos en el campo de la ciencia de la propaganda.

Palabras clave: E.A. Malov, política confesional, autobiografía, diarios misioneros, "extranjeros", misión ortodoxa, recurso educativo. 


\section{Introduction}

Evfimiy Aleksandrovich Malov (1835 - 1918) was one of the active missionaries of the Kazan diocese during the period of mass "falling away" of baptized "foreigners" to Islam or the performance of pagan rituals. He can be considered as an ideal type of a modern missionary scholar who knew the basics of Muslim theology, Christian apologetics, and could convey the "truths of the Christian faith" in the Tatar language. Due to his professional characteristics, E.A. Malov went repeatedly to various parishes to "exhort those who deviated from Orthodoxy" (The case of the bachelor E.A. Malov's dismissal to the village of Yelyshevo).

Throughout his life, E.A. Malov wrote missionary notes or diaries, most of which were not published by him. "Missionary Diaries" have been used by Russian and foreign researchers more than once to analyze the confessional policy of the Russian authorities in the Volga region in general and in the Kazan province in particular (Jerasi, 2013; Iskhakov, 2011; Werth, 2002; Geraci, 2001). The diaries are the part of his works devoted to missionary travels in the Kazan diocese during the second half of the 19th - early 20th centuries. In these travel descriptions, the author disclosed the goals of his travels, impressions and missionary conversations, both with Orthodox "foreigners" and with Muslims. The beginning of keeping diaries can be attributed to 1864. During this year, E.A. Malov was sent by the Kazan Theological Academy and the Spiritual consistory to the village of Elyshevo of the Kazan Diocese for missionary activity among the "fallen from Orthodoxy" to Islam, which was reflected in a separate book published by him (Malov, 1872). The autobiographical texts of the Kazan missionary allow us to take a fresh look at the specifics of Orthodox clergy activities in the context of the empire modernization and confessional and national diversity in certain regions of the state.

\section{Methods}

"Missionary Notes" coincided chronologically with the growing popularity of the autobiographical genre among the representatives of the "spiritual order". As L. Manchester showed, diaries, memoirs belonging to the clergy themselves and their children were important loci of memory of their social group, a form of the search expression for the concept of "national culture (Manchester, 2015). However, "missionary diaries" are a different example of an intellectual type of writing. The "missionary notes" almost do not reflect the events from private life, the relationships within the family, health and friendship issues. The content and presentation of the material from E.A. Malov's diaries are subordinated to the main goal - reflection on missionary activity in the Kazan diocese, namely, the reflections on missionary work, descriptions of meetings with priests and missionaries, baptisms of the diocese "foreigners", and conversations with Muslims about faith. Thus, autobiographical texts can be viewed from the point of view of G. Jahnke's methodology as a social practice aimed at social reality change (Jahnke et al., 2017; Salnikova, 2019).

\section{Results and Discussion}

The missionary "notes" were written by a "learned priest" indeed. EA Malov received his initial theological education at the Simbirsk Theological Seminary (1852 - 1858), and then at the Kazan Theological Academy (1858 - 1862). The period of his studies coincided with the institutionalization of missionary education at the Kazan Theological Academy. "Mass falling away" of newly baptized Orthodox Christians to Islam in the 1820-ies, which later became a characteristic feature of the religious situation in the Kazan diocese (Werth, 2002), provoked changes in the strategies of the Russian authority confessional policy in the region (Werth, 2000; Usmanova, 2019). These changes were reflected in the appearance of the first missionary departments at the Kazan Theological Academy (1854): anti-schismatic, anti-Muslim, and antiBuddhist (Znamenskiy 1891). A strong influence on the education of the Kazan missionary was exerted by the Professor of the Academy G.S. Sablukov, a well-known Islamic scholar at that time, 
who demanded compulsory knowledge of the Tatar and Arabic languages, Islamic theological literature and the skills of translating Orthodox liturgical literature into the Tatar language from his students (Znamenskiy 1891). E.A. Malov taught the students of the Academy the course on the history of missionary activity of the Orthodox Church among the Muslims of the Volga region (The case of internal tests of students of both courses at the Academy in December 1863). In the future, he pointed out the specifics of spiritual education at the Kazan Theological Academy both in his diaries and in publications, being already a teacher at the Theological Academy. In 1869 E.A. Malov wrote down the following information about the need for the Theological Academy in the region:

"The Kazan Academy must clarify the delusions that are rooted in the foreign inhabitants of the Kazan Territory, it must show all the absurdity and falsity of various pagan religions, with which non-baptized and partly baptized foreigners are content. It must also take on the labor of denouncing the Mohammedan religion, which is professed by a huge mass of Mohammedans of Kazan and other neighboring provinces" (Missionary notes of the priest, Kazan, the Epiphany Church by Efimiy Malov. Part 2. 1869 - 1871).

In an article published after the publication of the law on religious tolerance in the Russian Empire (1905), E.A. Malov described the purpose of opening missionary departments at the Academy more carefully, avoiding harsh judgments and statements about both paganism and Islam: "the desire of the authorities to describe scientifically the complex foreign issue in Russia and develop rational methods to bring the multi-million foreign world closer to the indigenous population of the empire on the basis of religion and culture" (Malov, 1906).

Despite the opening of missionary departments at the Kazan Theological Academy, parish priests and missionaries noted the lack of polemical literature in the second half of the 19th century. Thus, E.A. Malov was one of the first Russian missionaries who began to publish autobiographical travelogues describing his own missionary activities in various parishes of the Kazan diocese. He was largely aware of the shortcomings of his own "profession or science", he tried to formulate the disciplinary boundaries of "missionary science" with his methods, approaches and sources in his diaries. For E.A. Malov, missionary work is not so much the spread of Christianity among nations as a "scientific" opportunity to determine the truth and falsity of religious revelations and delusions.

In the spirit of European orientalism, E.A. Malov defended the need to develop missionary educational programs in the theological academy:

"We think that the Sovereign Emperor wants spread the faith of Christ among his subjects more, so that the charter would help rather than oppose. In fact, it is necessary to strengthen radically the doctrine of the Mohammedans and local languages. Everyone is convinced of this if we say that the falling away of the baptized Tatars into Mohammedanism is still going on" (Missionary notes of the priest, Kazan, the Epiphany Church by Efimiy Malov. Part 2. 1869 1871).

Therefore, it is not surprising that he saw in the missionaries not only clergymen, but also the agents of the imperial government: "Under these circumstances there is a positive and extreme necessity to establish missionary work somewhere in Russia, if not in Kazan, as firmly and wide as possible, so that the missionary pupils could be as missionaries, so as reasonable administrators of the eastern half of Russia" (Missionary notes of the priest, Kazan, the Epiphany Church by Efimiy Malov. Part 2. 1869 - 1871). The circumstances pointed out by the author are related to the TatarMuslim population living in the Kazan province, close to the baptized "foreigners". 
The purpose of the missionaries, as well as of the Academy itself, in E. A. Malov's opinion, was the refutation of "delusions" and "false" religions. According to the Kazan missionary, not only pagans and Muslims, but also Orthodox peasants and church hierarchs are subject to "delusions". He was skeptic about the "ritual aspect" of Orthodox peasants. During his trip to the village of Yelyshevo in the Kazan diocese (1864), he recorded the story of the baptized Tatar Kondraty Filipov about the miracles of Jesus Christ in Russian villages (Malov, 1872). E.A. Malov notes that the peasant-storyteller "has a firm faith", but at the same time he immediately adds "and on the other hand, you can see his extreme ignorance of the truths and miracles of the Gospel" (Malov, 1872). In other unpublished notes about the trip to the Buinsky district of the Kazan diocese (1865 - 1866), E.A. Malov recorded his conversation with an Orthodox peasant woman who urged him not to eat with the Muslim Tatars:

"When (the peasant woman - A.V.) began to deliver our supper, I saw that she took out a special cup and spoons for the Tatars from the shelf. Well, what can I give you, she turned to me? What? I asked you for milk, and you gave it. I don't need anything else. But the Tatars will eat milk, and you won't be eating with them; I can bring you some cabbage! Don't bother; I will also eat milk with the Tatars. Well, I'll give you a cup here. But why, there is a cup here and it is enough; I will eat with the Tatars. I see that you think that there is sin to eat together with the Tatars. Yes, darling. No, it is not a sin. The gospel law does not prohibit this, especially if the soul accepts. Only you need to thank God for everything" (Baptized Tatars of Buinsk district).

Malov wanted to give a special disciplinary status to "missionary science against Muhammadanism", which requires special educational training: knowledge of languages (Tatar, Arabic), theology and Christian apologetics, the methods of conducting polemical conversations. He translated, published his conversations with Muslims about the truths of religion. All of these publications were aimed at finding contradictions in Islamic theology. Robert Jerasi, who studied the polemical discourse by E.A. Malov in his autobiographical diaries, identified the following strategies for conversations with shakirds, i.e., the students of madrasahs, and mullahs: the search for logical inconsistencies in the Koran and other Islamic books, the opponents' misinterpretation of Islamic books, and the evidence of the immorality of the Muslim doctrine (Jerasi, 2013). The missionary in his conversations with Muslims constantly referred to the Gospel or the Koran to find the answers to polemical questions. In his opinion, turning to a direct historical source should form an objective opinion about religion. Thus, one entry in E.A. Malov's diary contains the following program for the polemical study of Islam:

"It is time now to start a scientific-critical publication of the Arabic text of the Koran. For the first time, one could make the following in the Quran: a) indications of all those passages that are taken from the Bible either literally or by thought; B) indications of some passages taken from Talmudic sources; c) indications of contradictions in the Koran, and finally D) indications to the places that are related to Judaism or Christianity, but distorted in the Koran, due to the ignorance of Muhammad" (Missionary notes (1885 - 1888)).

E.A. Malov considered these polemical conversations, recorded in his autobiographical diaries, as future teaching aids for missionaries and priests. In 1885, he left the following entry:

"Then I showed the manuscript to Nikolai Ivanovich (Ilminsky - italics AB) - my conversations with the Muhammadan scholar Girey Akhmerov about Adam. Nikolai Ivanovich Ilminsky took my manuscript to read, and said that it should certainly be published in May ..." (Missionary notes (1885 - 1888)).

Among other things, E.A. Malov left critical remarks on the incompetence of Kazan priests in the field of "missionary science." In 1871, he wrote down the following remarks about the teaching system at the Theological Academy:

"It's an amazing thing! The way our citizens of St. Petersburg look at missionary work. They think that if there were only a thousand baptized Tatars, it would not be worthwhile for them to study the language or teach in seminaries. Is it really necessary to forget that there are 400,000 
Mohammedans in the Kazan diocese, besides the baptized Tatars? (highlighted by the missionary) It's not worth learning and teaching Tatar language for 15,000 , there is no one to prepare for .... And for whom will all seminarians prepare, using more than 20 lessons for Latin? Is the Kazan Diocese filled with schismatic Latins, papists?" (Missionary notes of the priest, Kazan, the Epiphany Church by Efimiy Malov. Part 2. 1869 - 1871).

In reasoning that he could not openly publish, E.A. Malov constantly insisted on the need to increase the teaching hours of missionary sciences and negatively assessed their decrease. In addition to such remarks, E.A. Malov also wrote down critical reviews of the works of other authors that dealt with missionary polemic conversations. So, he criticized the draft article of the Kazan Bishop, His Grace Victorin (Lyubimov) on the methods of missionary activity. In his opinion, this work lacked "solidity." According to E.A. Malov, thoroughness was a deep knowledge of the Muslim doctrine, its canons, ceremonies and rituals.

That what it means, to take on the case without knowing it. We all imagine that it is so easy to prove the superiority of the Christian faith over the Mohammedan faith that it costs nothing; You sit down, take a pen and pile a lot of refutations, so that the other can only tell their Mohammedan why the latter is remain unanswered (Missionary notes of the priest, Kazan, the Epiphany Church by Efimiy Malov. Part 2. 1869 - 1871).

In addition to such critical reviews, the Kazan missionary often wrote about the meetings with priests, to whom he talked about polemical books necessary for missionary activity.

\section{Conclusions}

Indeed, the autobiographical diaries by E. A. Malov can be viewed as a certain social practice aimed at forming new ideas about the disciplinary boundaries of "missionary science" or discipline. In our opinion, the Kazan missionary viewed these diaries as certain teaching aids for Orthodox clergy, which could later be published and distributed to the diocese parishes.

Thus, E.A. Malov's autobiographical text is a direct continuation of his active missionary work. In the conditions of a modern society development, missionary work is perceived by him from a professional point of view. Therefore, it is not surprising that E.A. Malov viewed "Islam" and paganism not as a religion, but as a body of knowledge, delusions that can be refuted by referring directly to the source of knowledge. Seeing himself as a professional in his field, he criticized in his diaries those who had neither educational nor scientific training for missionary work.

\section{Acknowledgements}

The work is performed according to the Russian Government Program of Competitive Growth of Kazan Federal University.

\section{References}

The case of the bachelor E.A. Malov's dismissal to the village of Yelyshevo. // State Archives of the Republic of Tatarstan (hereinafter - SART). F. 10. fa. 1. DI 2557.

Jerasi R. Window to the East: empire, orientalism, nation and religion in Russia. Moscow: New Literary Review, 2013.

Iskhakov R.R. Missionary and Muslims of the Volga-Kama. Kazan, 2011;

Werth P. W. At the Margins of Orthodoxy: Mission, Governance, and Confessional Politics in Russia's Volga-Kama Region, 1827 - 1905. Ithaca, London, 2002.

Geraci R. Window on the East: National and imperial identities in Late Tsarist Russia. Ithaca; London: Cornell Univ. Press, 2001. 
Malov E.A. Essay on the religious state of the baptized Tatars who were influenced by Mohammedanism. Kazan (university printing house), 1872.

Manchester L. Priests in the world: clergy, intelligentsia and the formation of modern selfconsciousness in Russia. Moscow: New Literary Review, 2015.

Jahnke G. Caritas Pirkheimer, Martin Luther and other clergy. Autobiographical essay as a social practice in German-speaking countries (XV and XVI centuries) // Autobiographical essays in an interdisciplinary research space: people, texts, practices. M.: Biblio-Globus, 2017. pp. 149 - 196.

Salnikova A.A. City of Childhood in Autobiographical Narratives of Kazan Historians // Vestnik Permskogo Universiteta-istoriya-perm University Herald-history. 2019. Volume 44. Issue 1. pp. 129-137.

Werth P. W. Inorodtsy on Obrusenie: Religious Conversion, Indigenous Clergy, and the Politics of Assimilation in Late-Imperial Russia. Ab imperio. 2000. № 2. pp. 105 - 134.

Usmanova D.M. Transformation of Islamic institutions in revolutionary Russia: The Orenburg Muslim spiritual assembly and the Muslim clergy of the Volga-Ural region in 1917 - Early 1918 // State, Religion and Church in Russia and Worldwide. 2019. № 1-2 (№ 37). pp. 434-462.

Znamenskiy P.V. History of the Kazan Theological Academy during the first (pre-reform) period of its existence (1842 - 1970). Kazan, 1891. Issue 1.

The case of internal tests of students of both courses at the Academy in December 1863 // SART. F. 10. fa. 1. C. 2263.

Missionary notes of the priest, Kazan, the Epiphany Church by Efimiy Malov. Part 2. 1869 - 1871 // Department of Manuscripts and Rare Books of the Scientific Library named after N.I. Lobachevsky (hereinafter - DMRB SL named after N.I. Lobachevsky) F. 7. DI 14.

Malov E.A. Missionary department at the Kazan Theological Academy and internal mission in Russia // Church and social life. 1906. No. 18.

Baptized Tatars of Buinsk district (travel notes by E. Malov). // DMRB SL named after N.I. Lobachevsky. F. 7. DI 2.

Missionary notes (1885 - 1888) // DMRB SL named after N.I. Lobachevsky. F. 7. DI 17. 